\title{
HISTORICAL-ECONOMIC KNOWLEDGE AS THE BASIS OF THE THEORETICAL LEVEL OF ECONOMIC THINKING
}

\author{
Aidar M. Tufetulov ${ }^{1}$ \\ Gulnara N. Hadiullina ${ }^{2}$ \\ Rival R. Shakirov ${ }^{3}$ \\ Andrey S. Zayats ${ }^{4}$
}

Abstract: Economic theory as an independent science arose in the period of the formation of modern market relations. The economic thought history as a separate branch in the system of economic sciences took shape in the first half of the XIX century. The tradition of Russian economic thought at all stages of its development was attention to historical trends and factors of socioeconomic development. The reason for this is in the specifics of Russia's socioeconomic and spiritual development. XIX century is characterized by the struggle of old and new trends in the economic system of Russia. In these conditions, representatives of various branches of economic thought appealed to the historical experience of the country and humanity in order to prove the truth of their position. The paper presents an analysis the historical process of emergence, development, struggle, and the changing of economic ideas. The main attention is paid to the analysis of the main directions of modern economic theory underlying the decision-making at macro and microeconomic levels. The content of the historical and economic knowledge functions: worldview, practical, axiological, factual and methodological, is defined. The necessity of studying the provisions of alternative economic schools is substantiated, what is considered as a prerequisite for the formation of general cultural and professional competencies of specialists in the field of economics.

Keywords: History of economic doctrines, economic ideas of the Ancient

\footnotetext{
${ }^{1}$ Kazan Federal University. E-mail: verkbund@gmailcom. Tel. : +7 (906) 3219099.

${ }^{2}$ Kazan Federal University. E-mail: verkbund@gmailcom. Tel. : +7 (906) 3219099.

${ }^{3}$ Kazan Federal University. E-mail: verkbund@ gmailcom. Tel. : +7 (906) 3219099.

${ }^{4}$ Kazan Federal University. E-mail: verkbund@ gmailcom. Tel. : +7 (906) 3219099.
} 
East and the ancient world, views were not represented in Soviet mercantilism, marginalism, historiography.

Keynesianism, neoliberalism, theory of supply-side economics,

\section{Methods}

The methodological basis of the

\section{Introduction}

The beginning of market reforms in the 90-ies of XXth century was marked by a surge of interest in historical and economic knowledge which began to be used as a source to justify the position of newly emerging schools and trends, to confirm (refute) the governmental program documents aimed at implementing structural transformations in society $[7 ; 10]$. In this period, Western economic thought was of particular interest, what has been reflected in numerous studies of the achievements of foreign economists [3; $5 ; 9]$. There was a return of the names of Russian authors whose works contradicted the principles of the Marxist concept that dominated the conditions of the administrative economy: N. D. Kondratiev, A. V. Chayanov, G. Ya. Sokolnikov, et al. At the same time, interest grew to the scientific heritage of N.N. Baransky, N. N. Kolosovsky, N. N. Nekrasov, A. E. Probst, Yu. G. Saushkin and others whose multidimensional study is the works on the economic thought history and economic history of Russia and foreign countries, the fundamental provisions of modern, primarily, institutional economic theory, the works of representatives of domestic and foreign economic schools and trends, work in philosophy, sociology, culture, and interdisciplinary socioeconomic research. There are two approaches to historical and economic analysis: absolutism and relativism. Absolutism considers the logic of the research subject development, which consists in moving from the false to the true, from the simple to the complex. Relativism considers every single theory proposed in past eras as a more or less accurate reflection of socio-economic conditions. Relativism in its extreme form is represented as a class approach according to which the ideas of economists are a reasonable justification for class or group interests. At the same time, the nature of the interrelationships within a range of questions where this or that theory or doctrine can make sense is 
ignored. Although every commentator of the economic thought history can be attributed to one pole or another, yet the positions of modern economistshistorians can not be classified as unambiguously relativistic or absolutist.

The basis for the periodization of the world economic thought history is its belonging to a certain epoch. The periodization proposed in this study is presented in three stages. In accordance with specific qualitative changes in the economy, the following stages in the development of economic thought are distinguished:

1. Economic doctrines of the premarket economy;

2. Economic doctrines and concepts of the era of unregulated market economy;

3. Economic concepts of the era of a regulated market economy.

\section{Results}

The emergence of market relations in the Modern times era led to the emergence of mercantilism which is the first attempt in the economic thought history to substantiate the economic policy of a state. Mercantilism is not an economic science, since its main provisions are the result of not a theoretical analysis, but a simple description of observed phenomena and, in part, their classification.

In its historical development, the mercantilism concept goes through two stages. Early mercantilism (monetarism) was aimed at solving the problem of gold accumulation nationwide through manipulation in the sphere of monetary circulation. The central point of mature mercantilism is the doctrine of the active trade balance as an indispensable condition of national prosperity. Representatives of mercantilism are T. Men, J. B. Colbert, A. de Montchretien.

In Russia, mercantilism was realized in the economic policy of Peter the Great in the first half of the 18th century. Adoption of a legislative act permitting the owners of manufactories to purchase land with peasants assigned to it, which significantly reduced the costs of production of domestic goods; the introduction in 1724 of a protectionist tariff setting customs duties to imported industrial goods in the amount of 70-75 percent of the selling price of the goods; monetary reform and the introduction of copper money into 
circulation; the prohibition under the death penalty of exporting gold and silver from the country and other steps of the state aimed at protecting the emerging industry were clearly mercantilistic in nature. The ideas of late mercantilism were reflected in the work by I.T. Pososhkov (1652 - 1726) "On poverty and wealth" completed in 1724 and intended for Peter the Great.

Classical political economy arose during the period of the establishment of capitalist relations. The development of manufactory capitalism has led to the fact that the sphere of production becomes the main source of profit.

Unlike mercantilism, within the framework of the classical school of political economy, and for the first time in the economic thought history, a common basis of science was created: a unified theory of production and distribution, an analysis of the operation of these abstract principles on historical material, and a number of examples of their application in economic policy. An analysis of domestic economic relations comes in place of a superficial generalization of economic phenomena within the framework of mercantilism. Material production became the object for analysis by representatives of the classical school.

Classical economic theory derives prices from the "natural" norms of remuneration for the three factors of production which are investigated by three independent sections of a single system: the rent, capital, and wages theories. Representatives of the classical school (U. Petty, A. Smith, D. Ricardo, and others) used the developed analytical tools, including such methods of economic phenomena analysis as analysis and synthesis, induction and deduction, the principle of the historical and logical unity, etc.

Marginalism (translated from the French, "marginal" means the "ultimate") is a theory that explains processes and phenomena based on the use of marginal, that is, incremental values of economic indicators, extreme values or states. In the economic literature, the "marginalist revolution" means by almost simultaneous but not dependent discovery in the early 70 s of XIX century by W. St. Jevons (England, Manchester), K. Menger (Austria, Vienna), L. Walras (Switzerland, Lausanne) of the diminishing marginal utility principle. However, in 1878, a book by the German author G. Gossen 
was found in the British Museum where the beginnings of a marginal analysis were presented.

Traditionally, two stages of the "marginalist revolution" stand out:

The first stage refers to the 7080-ies of XIX century and marked by the works of K. Menger, U. Jevons, L. Walras, O. von Böhm-Bawerk, and F. Wieser. For this period of development of marginalism, the cardinal approach to the evaluation of utility and demand is characteristic, that is, the possibility of estimating an utility in conditional units, "utiles" (from the English expression "utility of good") has been supposed.

In the 90 years of the XIX century a second stage in the development of marginalism began, for which a rejection of subjectivism is characteristic. This stage is considered as an extension of classical economic theory, and with its appearance the neoclassical trend in economic thought is associated. In this period, the works of A. Marshall, J. B. Clarke, V. Pareto have been developed.

Several schools emerged within the framework of marginalism; they differed somewhat in the nature of the problems analyzed. Among them there were the Austrian school (K. Menger, E. von Böhm-Bawerk, F. von Wieser), the Lausanne school (L. Walras), the Cambridge school (A. Marshall), and the American school (J.B. Clarke).

Formation of a system of regulated market economy in the early $\mathrm{XX}$ century led to a qualitative change in economic ideas, which was reflected in the formation of the economic system of J.M. Keynes. Keynesian economic theory has become dominant in economic thought since the world economic crisis of 1929-33 and "great depression" and, being largely supplemented and modified, it then formed the basis of modern macroeconomics.

J. M. Keynes rejected the J. -B. Say's law, grounding on that the interest rate is not able to bring household savings and investment plans of entrepreneurs into line. The reason for this is the fact that savings subjects and investors are from different social groups, and are guided by different motives for decision-making. At the same time such decisions are not related to the interest rate for savings entities.

J. M. Keynes created a simple model of income determination, which reveals the mechanism for the multiplicative effect of increasing 
aggregate income when the expenditures are changed. The starting point in the multiplier theory is to determine the role of investment in the growth of real aggregate output and employment. The growth of investment causes employment, income and consumption growth. The initial increase in employment caused by new investments leads to an additional increase in employment and income due to the need to meet the demand of additional workers. According to J. M. Keynes, the multiplier indicates that when there is an increase in the total amount of investment, then the income increases by an amount that is $\mathrm{M}$ times larger than the increase in investment. The multiplier theory was further developed within the framework of neo- and post-Keynesian theory in the works by P. Samuelson, R. Harrod, H. Haberler, E. Hansen, and others. A dynamic multiplier model was also created.

Analyzing the theory of state regulation of economic processes, it should be noted that J. M. Keynes distinguished three groups of factors in his analysis, namely:

- initial (preset) variables which include the number and quality of the workforce, the technological and social organization of the society, etc.

- independent variables, that is, the marginal efficiency of capital, the rate of interest, the propensity to consume, etc. - dependent variables, which include the volume of employment and the actual volume of national production.

\section{Discussion}

The economic crisis of 1979-81 became a crisis of the Keynesian model of state regulation. Under its influence, a neo-conservative model of state regulation of the economy was formed.

Representatives of the neoconservative wave rely on the neoclassical school theories. The starting points of the neoclassical direction are the following points:

- The market system is able to ensure the full use of resources in the economy, therefore, the situation where the level of expenditure will be insufficient to purchase products produced at full employment is impossible;

- Violations of the equilibrium state of the economy are due to external causes, while such control levers as price, wages, interest rate are included, so that a reduction in total expenditures does not 
entail a reduction in real output, employment and real incomes.

Within the conservative sect, a number of directions and schools are developing. The most influential of those were: the Chicago school that opposed to Keynesianism in the 1950s and 1960s the monetarism doctrine which was a theory based on ideas about the decisive influence of the money supply on prices, inflation, and the course of economic processes; the rational expectations school which spoke about the "new classical theory" proving the futility of any systematic stabilization policy; and the Virginia School which advocates the rejection of state intervention through non-traditional arguments for the classical sect.

The general conclusion of the neoclassical theory was that, although unexpected price fluctuations can cause short-term macroeconomic instability, the economy remains stable in the long run with output volume corresponding to the level of full employment.

In the late 19th and early 20th centuries, the role of the state in regulating economic processes increased. In these conditions, the need to analyze the political and legal aspects of the market system is brought to the forefront. This led to the emergence of institutionalism.

Institutionalism goes a long way in its development. By the 1930s, the old negative school of institutionalism was aroused, which representative were T. Weblen (18571920), J.R. Commons (1862-1945), W. K. Mitchell (1874-1948). In post-war years, late institutionalism has been formed, based on positivism describing the contradictions of the market economy and offering its own prescriptions for the transformation of economic policies based on the Keynesian theory. This period is represented by economic systems developed by J. M. Clark, A. Burley, G. Minz. In the 1960s neoinstitutionalism, or social and institutional direction, was being formed. Representatives of this sect were, first of all, J.K. Galbraith, the creator of the convergence theory, and R. Heilbroner.

Representatives of the institutional sect made a great contribution to the development of modern management theory, the system organization theory, the general theory of systems, and in the understanding of the economic cycle mechanism. 
Neo-liberalism is the sect, the main principle of which laid by $\mathrm{A}$. Smith, is reduced to minimizing the state impact on the economy and granting maximum possible freedom of action to entrepreneurs. First of all, the principle of free pricing, the principle of the leading role of private property and nonstate economic structures are among the principles of neoliberalism. The state in this system should perform, as the supporters of this direction put it figuratively, a "night watchman" or "sports arbiter" role. The economic systems of Friedrich von Hayek (18991984), Joseph Schumpeter (1883-1950), Ludwig Erhard (1897-1977), author of the book "Welfare for All" (1956), can be referred to this sect.

Already in the 1930s, the ideas of the neoliberal nature were opposed to the Keynesian ideas of government regulation of the economy, which limited the system of free competition. Centers were being set up to develop measures alternative to government regulation of the economy, which should facilitate the practical implementation of the economic liberalism ideas. In Germany this was the Freiburg school which included W. Euken, W. Repke, L. Erhard, in the USA - the Chicago school.
In the 1930 s an attempt was made to develop a unified scientific and practical platform. In 1938, a conference was held in Paris, which united the supporters of neoliberal ideas about the world. It proclaimed the need for government assistance to return the rules of free competition and ensure their implementation by all economic entities; it also formulated the principles of building a neoliberal economic system: the priority of private property, freedom of transactions, and free markets. These principles can be reviewed by the state only in extreme situations - in the conditions of war, natural disaster, cataclysm, etc.

Since 1948, these ideas have become the state doctrine of the government of Erhard Adenauer (Germany). The yearbook "Ordo" published by W. Euken since 1948, becomes a mouthpiece of neoliberal ideas.

Proponents of the supply-side economics theory proceed from the assumption that low rates of growth in labor productivity and real output are the ultimate cause of stagflation and general mediocre functioning of the economy in the 1970s. Keynesian theory can not cope with stagflation, since it focuses on 
aggregate demand, while only a supplyoriented policy can overcome negative developments in the economy.

Proponents of supply-side economic theory focused on supply note that the growth of state influence causes an increase in the country's tax payments in the absolute and relative (if to compare the amount of taxes with the amount of national income) amounts. Proponents of the supply-side theory believe that most taxes are transformed into costs of entrepreneurs and shifted to consumers in the form of higher prices. The result is an inflation of costs reflected in the shift of the aggregate supply curve to the left.

\section{Summary}

Knowledge of the legacy of the past will allow the modern generation of economists not to reinvent the wheel, but, relying on a huge historical and economic material, to create new and improve existing theoretical systems, to form an effective economic policy at macro and micro levels. Due to objective circumstances, this paper could not fully analyze the entire heritage of mankind in the history of economic doctrines. Outside of consideration are problems of
Russian economic thought, economic doctrines of the Middle Ages, etc. These and other questions can be studied with the help of numerous works by representatives of Russian and foreign economic schools.

\section{Acknowledgements}

The work is carried out according to the Russian Government's Program of Competitive Growth of Kazan Federal University.

\section{Bibliography}

Anikin A. V. Youth of science. Moscow: Politizdat, 1975.

Anthology of economic classics: In 2 volumes / Composed by I.A. Stolyarov. - Moscow: MP "Ekonov", 1991.

Blaug M. Economic thought in retrospect / Translation from English. 4th edition. - Moscow: Delo Ltd, 1994.

The World Economic thought history: In 6 vols. - M, 1987. - V. 1; 1988. - V. 2; 1989. - V. 3; 1990. - V. 3; 1991. - V. 4; 1992. - V. 5. 
Charles Gide, Charles Rist. History of

economic doctrines: Translation from

English. - Moscow: The Economy, 1995.

History of economic doctrines / Edited by V. A. Zhamin, E. G. Vasilevsky. Moscow: Publishing house of Moscow University, 1989. - Part 1

History of economic doctrines / Edited by A. G. Khudokormov. - Moscow: Publishing house of Moscow University, 1994. - Part 2.

Keynes, J. M. General theory of employment, interest and money. - M. , 1978.

Negishi Takashi. History of Economic Theories / Translation from English; Edited by L.L. Lyubimov, V.S. Avtonomov. - Moscow: Aspect Press, 1995.

G. Khadiullina. History of economic doctrines: Textbook / G.N. Khadiullina, Sh. I. Enikeev. Kazan: Ekopolis, 1998. $111 \mathrm{p}$ 